\title{
Obstetrical Anesthesia
}

Editors

MAY C.M. PIAN-SMITH

REBECCA D. MINEHART

\section{ANESTHESIOLOGY CLINICS}

www.anesthesiology.theclinics.com

Consulting Editor

LEE A. FLEISHER

December 2021 • Volume $39 \bullet$ Number 4 